\title{
PENERAPAN MODEL MULTILITERASI UNTUK MENINGKATKAN KEMAMPUAN MEMBACA PEMAHAMAN SISWA SEKOLAH DASAR
}

\author{
Sigit Vebrianto Susilo, Dudu Suhandi Saputra, Gita Risda Garnisya \\ sigitvebriantosusilo@unma.ac.id,d.suhandi.s@gmail.com, gitarisdagarnisya@gmail.com \\ Universitas Majalengka
}

Bahasa adalah suatu sarana penyampaian ilmu pengetahuan. Salah satu kompetensi utama yang harus dikuasai dalam rangka membentuk keterampilan berbahasa adalah kemampuan membaca pemahaman yang tinggi. Kenyataan yang terjadi pada siswa kelas V SDN Trajaya III ditemukan bahwa kemampuan membaca pemahaman siswa tergolong rendah, dibuktikan dengan hasil tes prasiklus dengan keberhasilan pembelajaran yang hanya sebesar 30\% siswa yang tuntas. Oleh karena itu penulis melakukan penelitian yang bertujuan untuk meningkatkan kemampuan membaca pemahaman siswa kelas V SDN Trajaya III Kecamatan Palasah Kabupaten Majalengka pada tahun 2017 dengan menerapkan model Multiliterasi. Penelitian tindakan kelas ini menggunakan model John Elliot sebanyak 3 siklus. Pengumpulan data yang digunakan yaitu lembar tes kemampuan membaca pemahaman,lembar observasi aktivitas siswa dan guru, dan dokumentasi. Data yang diperoleh, dianalisis, dan direfleksi dengan menggunakan metode deskriptif kualitatif, dapat ditarik kesimpulan bahwa penerapan model Multiliterasi pada materi menyimpulkan cerita anak telah memperlihatkan peningkatan kemampuan membaca pemahaman siswa pada setiap siklusnya. Berdasarkan hasil penelitian yang dilakukan selama 3 siklus di dasarkan penilaian proses dan hasil yang diperoleh pada siswa pada siklus I nilai rata-rata siswa sesuai dengan rentang nilai model multiliterasi didapatkan data bahwa siklus I rata-rata nilai proses membaca pemahaman yaitu 2,83 termasuk dalam kategori baik dengan persentase ketuntasan $14 \%$ dan hasil kemampuan membaca pemahaman siklus I yaitu 2,27 termasuk dalam kategori kurang baik dengan persentase ketuntasan $7 \%$. Sedangkan pada siklus II rata-rata nilai proses membaca pemahaman yaitu 3,12 termasuk dalam kategori baik dengan persentase ketuntasan $67 \%$ dan hasil kemampuan membaca pemahaman siklus II yaitu 2,70 termasuk dalam kategori cukup baik dengan persentase ketuntasan $48 \%$. Terakhir pada siklus III rata-rata nilai proses membaca pemahaman yaitu 3,51 termasuk dalam kategori sangat baik dengan persentase ketuntasan 96\% dan hasil kemampuan membaca pemahaman siklus III 3,03 termasuk dalam kategori baik dengan ketuntasan 85\%. Dengan demikian penerapan model Multiliterasi dapat meningkatkan kemampuan membaca pemahaman siswa. Oleh karena itu peneliti merekomendasikan model Multiliterasi dalam pembalajaran Bahasa Indonesia

Kata Kunci: Model Multiliterasi, Membaca Pemahaman 


\section{PENDAHULUAN}

Sejalan dengan perkembangan dunia tentang makna pendidikan, pendidikan dihadapkan pada sejumlah tantangan yang semakin berat. Pendidikan hendaknya mampu menghasilkan sumber daya manusia yang memiliki kompetensi utuh. Berbeda dengan beberapa dekade yang lalu, kompetensi sumber daya manusia saat ini lebih dititikberatkan pada kompetensi berpikir dan berkomunikasi. Kompetensi berpikir artinya bahwa diharapkan sumber daya manusia hendaknya memiliki kemampuan berkomunikasi dalam rangka bekerja sama dan menyampaikan ide-ide kritis dan kreatifnya.

Bertemali dengan karakteristik abad ke-21 kemampuan literasi semakin berkembang, Morocco, et al (dalam Abidin: 2015) menyatakan bahwa pada abad ke dua puluh satu ini minimalnya ada empat kompetensi terpenting yang harus dikuasai siswa. Keempat kompetensi abad ke-21 tersebut adalah kompetensi pemahaman konsep , kompetensi berpikir kritis, kompetensi berkolaborasi dan berkomunikasi.

Pada tahun 2015 lalu didapatkan data survei yang mencakup pemahaman akan sains, matematika dan membaca dari hasil studi yang dilakukan Programme for International Students Assessment (PISA) yang menyatakan bahwa "Indonesia berada di urutan ke 69 dari 76 negara" (dalam OECD: 2013). Selanjutnya berdasarkan studi pendahuluan pada saat proses pembelajaran Bahasa Indonesia, diketahui bahwa kemampuan membaca pemahaman siswa kelas V SDN Trajaya III masih rendah. Berdasarkan hasil tes prasiklus diperoleh informasi bahwa hanya $30 \%$ atau sebanyak 8 orang siswa yang mengalami ketuntasan dalam hal membaca pemahaman dan $70 \%$ atau sebanyak 19 orang siswa lainnya mengalami ketidak tuntasan.

Keberhasilan peserta didik dalam mengikuti kegiatan belajar mengajar di sekolah banyak ditentukan oleh kemampuan membaca pemahaman. Sebagian besar pengetahuan yang disajikan dalam bentuk bahasa tulis sehingga menuntut anak harus melakukan aktivitas membaca untuk memperoleh pengetahuan yang bermakna. Kemampuan membaca pemahaman merupakan bekal dan salah satu kunci keberhasilan siswa dalam menjalani proses pendidikan.

Membaca merupakan suatu kegiatan yang rumit yang melibatkan banyak hal, tidak hanya sekedar melafalkan tulisan, tetapi juga melibatkan aktivitas visual, berpikir, psikolinguistik, dan metakognitif. Membaca menerjemahkan simbol tulis ke dalam katakata lisan. Sebagai suatu proses berpikir membaca mencakup aktifitas pengenalan kata, pemahaman literal, interpretasi, membaca kritis, dan pemahaman kreatif. Kern (dalam Yukselir : 2014) menyatakan bahwa "Reading is a complex skill which occurs with the combination of attention, emmory, perceptual processes, and comprehension processes. And it is the mostly beneficial skill obtain knowledge and raise information." Bertemali dengan pernyataan di atas, Tarigan (2008: 7) yang mengungkapkan bahwa "membaca adalah suatu proses yang dilakukan untuk memperoleh pesan yang hendak disampaikan oleh penulis melalui media kata-kata bahasa tulis". Menurut pandangan tersebut membaca sebagai proses visual merupakan proses menerjemahkan simbol tulis ke dalam bunyi. Oleh sebab itu, proses pembelajaran membaca perlu di arahkan untuk dapat mengembangkan kemampuan berpikir tingkat tinggi siswa. Hal ini sejalan dengan pendapat Susilo (2016a) yang mengatakan bahwa pembelajaran membaca pemahaman seyogianya mampu menumbuhkan pemikiran kritis dan kreatif sehingga timbul sebuah pemahaman komprehensif.

Selanjutnya Broek \& Espin (dalam Moore: 2017) menyatakan bahwa 'reading comprehension is a complex interaction among automatic and strategic cognitive processes that enables the reader to create a mental representation of the text'. Susilo (2016b) menyatakan bahwa membaca pemahaman merupakan kegiatan memahami isi bacaan yang dibacanya. Wolley (2011: 15) memiliki pendapat tentang bagaimana membaca pemahaman membangun model situasi mental "Reading comprehension is the process of making meaning from text. The goal, therefore, is to gain an overall understanding of what is described in the text rather than to obtain meaning from isolated or sentences". 
Selanjutnya salah satu model dalam pembelajaran yang merupakan visioner yang dapat digunakan untuk menjawab segala tantangan di abad ke-21 dalam dunia pendidikan adalah model pembelajaran multiliterasi. Pengembangan model multiliterasi dalam konteks keIndonesiaan dikembangkan oleh Dr. Yunus Abidin, M.Pd. Istilah multiliterasi merupakan bagian akhir perkembangan konsep literasi yang pada dasarnya sring mengalami perubahan sesuai dengan perkembangan jaman. Model ini juga merupakan konsep yang terinspirasi dari Morocco, et al (dalam Abidin, 2016: 33) yang menegaskan 'bahwa dalam abad ke-21 terdapat empat kompetensi penting yang harus dimiliki oleh manusia yakni kompetensi pemahaman yang tinggi, kompetensi berpikir kritis, kompetensi kolaborasi dan kompetensi berkomunikasi'. Selanjutnya kompetensi tersebut dilandasi dan juga difasilitasi oleh keterampilan multiliterasi. "Pengembangan konsep multiliterasi dalam dunia pendidikan sebenarnya tidak pernah terlepas dari konsep pedagogik berbasis seni, multiple ways of knowing, dan multipelintelegensi bagi siswa" (Abidin, 2015: 57). Sejalan dengan hal tersebut multiliterasi juga diyakini mampu mengembangkan kreativitas tingkat tinggi sebagai keterampilan penting bagi siswa. Aplikasi dari teori multiliterasi dalam pembelajaran sudah banyak dilakuakan dalam sepuluh tahun terakhir. Sebagai perintis konsep multiliterasi, New London Group 1996 dalam Pedagogy of Multiliteracies menyatakan bahwa "selain adanya konsep conventional reading and writing, digital literacy, visual literacy dan critical literacy menjadi aspek penting dalam praktik multiliterasi di kelas" (Abidin: 2015). Perspektif multiliterasi juga mengadopsi pendekatan pedagogi, dalam New London Group 1996 (dalam Boche: 2014) 'teacher and managers are seen as designers of learning processes and environments, dictating what those in their charge should think and do'. Guru sebagai perancang pembelajaran sekaligus perancang lingkungan belajar, bukan sebagai pemimpin yang hanya mendikte apa yang harus dilakukan oleh siswanya. Guru perlu membekali siswa dengan keterampilan yang akan membantu siswa agar berhasil berpartisipasi menjadi agen transformasi dalan proses perencanaan.
Oleh sebab itu, sintaks dasar model pembelajaran multiliterasi terdiri atas tiga fase besar yakni fase praaktivitas, fase aktivitas, dan fase pascaaktivitas. Menurut Abidin (2015: 105) tahapan fase pembelajaran multiliterasi dapat dijelaskan sebagai berikut : (1) Fase Praaktivitas, (2) Fase Aktivitas, dan (3) Fase Pasca Aktivitas

\section{METODE PENELITIAN}

Pendekatan penelitian yang digunakan adalah Penelitian Tindakan Kelas. Penelitian tindakan kelas yang peneliti gunakan yaitu menggunakan model John Elliot. John Elliot memiliki konsep 3 siklus yang lebih fleksibel dibandingkan Kemmis dan Mc Taggart dan setiap siklus terdiri dari 3 tindakan (Arifin, 2009). Teknik pengumpulan data yang akan digunakan dalam penelitian ini adalah menggunakan teknik tes dan non tes. Tes yang digunakan adalah tes kemampuan membaca pemahaman. Sedangkan teknik non-tes yang digunakan adalah observasi, dokumentasi dan wawancara.

\section{HASIL PENELITIAN}

Hasil penelitian yang didapatkan setelah dilakukan tindakan pada siswa kelas $\mathrm{V}$ SDN Trajaya III sesuai dengan rencana yang telah disusun dalam penelitian ini, ternyata kemampuan membaca pemahaman menunjukan pada arah yang lebih baik. Di bawah ini merupakan persentase peningkatan hasil tes kemampuan membaca pemahaman siswa :

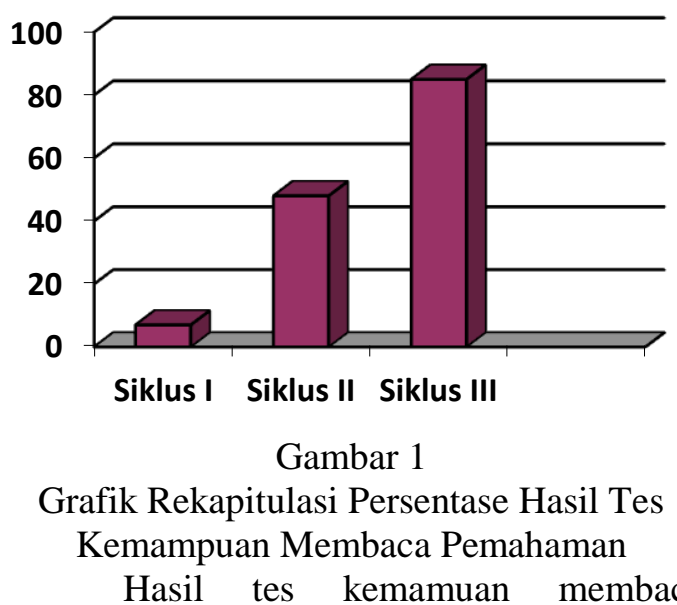
pemahaman siklus I didapatkan data bahwa jumlah siswa yang telah tuntas sebesar $7 \%$ atau 2 orang dan $93 \%$ atau sebanyak 25 siswa belum tuntas dalam tes kemampuan membaca 
pemahaman. Hal tetsebut dapat dikategorikan sebagai hasil yang sangat kurang baik dikarenakan berbagai adanya kelemahan dalam proses pembelajaran yang kurang efektif. Maka dari itu guru berupaya meningkatkan hasil tes membaca pemahaman melalui perbaikan proses membaca pemahaman yang sudah di paparkan sebelumnya. Tindakan yang diambil guru dalam siklus II merupakan hasil refleksi dari kegiatan siklus I. Hasil yang diperoleh yaitu pada siklus II siswa mampu menyimak dan menerima informasi secara lebih mudah karena guru mengubah cara penyampaian informasi dengan lebih sederhana dan menarik dibantu dengan media pembelajaran yang telah diperbaharui.

Selain itu, guru lebih memfasilitasi siswa dengan membangun pengetahuan awal yang sudah dimiliki siswa dan menghubungkannya dengan pengetahuan baru siswa. Seperti dalam membaca sebuah teks saat membaca teks putaran pertama yang kemudian dilanjutkan dengan membaca kemabli teks putaran kedua hal tersebut ternyata mampu menigkatkan hasil tes membaca pemahaman pada siklus II menjadi 48\%. Hal tersebut sesuai dengan pendapat Anderson, Pearson dan Teng (dalam Kurniawan: 2016) bahwa membaca pemahaman dilihat sebagai proses membaca dalam menginterpretasikan informasi baru dan menggabungkan informasi tersebut ke dalam struktur memori. Keterampilan membaca pemahaman merupakan kemampuan seseorang dalam bekerja secara motorik dan mengoptimalkan fungsi mental yang berhubungan dengan kegiatan kognitif untuk dapat memahami isi bacaan secara detail serta dapat dapat memaknai bacaan dengan cepat dan tepat.

Setelah kegiatan siklus II selesai ternyata peneliti masih menemukan beberapa kelemahan yang mengharuskan peneliti melanjutkan kegiatan pada siklus III. Perencanaan siklus III dilakukan dengan sangat matang agar kemampuan membaca pemahaman siswa menjadi lebih baik. Pada siklus III guru menyadari bahwa guru bukanlah seorang pemimpin yang mendiktekan pembelajaran yang harus dilakukan oleh siswanya. Menurut perspektif multiliterasi yang mengadopsi pendekatan pedagogi, dalam New London Group 1996 (dalam Boche: 2014) guru merupakan sebagai perancang pembelajaran sekaligus perancang lingkungan belajar, bukan sebagai pemimpin yang hanya mendikte apa yang harus dilakukan oleh siswanya. Guru perlu membekali siswa dengan keterampilan yang akan membantu siiswa agar berhasil berpartisipasi menjadi agen transformasi dalan proses perencanaan.

Berdasarkan dari hasil tes evaluasi dan lembar observasi aktifitas siswa, hasil yang diperoleh menunjukan bahwa membaca pemahaman cerita anak mengalami peningkatan dari sebelum dilaksanakannya tindakan. Pada kondisi awal, kemampuan membaca pemahaman siswa masing rendah. Oleh karena itu, peneliti mencoba memberikan solusi untuk memecahkan permasalahan tersebut. Peneliti menggunakan model Multiliterasi dalam upaya memecahkan permasalahan tersebut. Pada akhirnya hasil tes kemampuan membaca pemahaman pada siklus III dapat meningkat secara tajam menjadi $85 \%$ siswa tuntas dalam mengerjakan tes kemampuan membaca pemahaman.

Setelah melakukan tindakan dengan menggunakan model Multiliterasi pada pembelajaran membaca pemahaman di kelas $\mathrm{V}$, hasil evaluasi menunjukan adanya peningkatan pada persentase ketuntasan siswa. Kegiatan belajar mengajar menjadi lebih efektif. Hal tersebut menunjukan bahwa pembelajaran membaca pemahaman menggunakan model Multiliterasi berpengaruh pada kemampuan membaca pemahaman siswa.

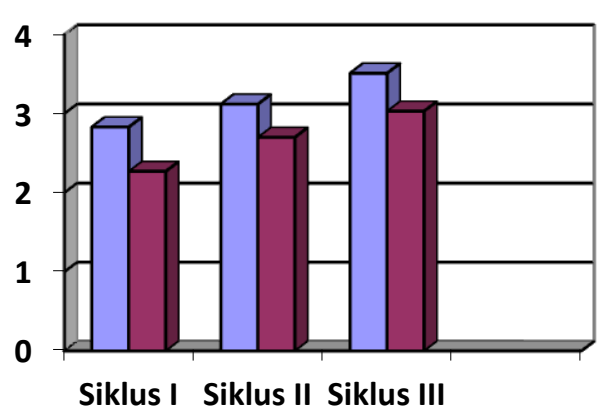

Gambar 4.22

Grafik Rekapitulasi Peningkatan Persentase Membaca Pemahaman

Di bawah ini merupakan tabel rentang nilai membaca pemahaman model multiliterasi : 
Tabel 4.28

Tabel Rentang Nilai

\begin{tabular}{cccc}
\hline No & $\begin{array}{c}\text { Rentang } \\
\text { Nilai }\end{array}$ & Kriteria & Presentase Nilai \\
\hline 1 & $3,20-4,00$ & $\begin{array}{c}\text { Sangat } \\
\text { Baik }\end{array}$ & $(80-100)$ \\
\hline 2 & $2,80-3,19$ & Baik & $(70-79)$ \\
\hline 3 & $2,40-2,79$ & Cukup & $(60-69)$ \\
\hline 4 & $\begin{array}{c}\text { kurang dari } \\
2,40\end{array}$ & Kurang & $\begin{array}{c}(\text { kurang dari } \\
60 \%)\end{array}$ \\
\hline
\end{tabular}

Berdasarkan grafik 4.22 persentase dan nilai rata-rata ketuntasan belajar siswa pada kondisi awal sampai siklus III menunjukan adanya perubahan yang lebih baik. Hal tersebut terlihat dari adanya peningkatan ketuntasan proses membaca pemahaman dan hasil membaca pemahaman.

Dalam peningkatan proses kemampuan membaca pemahaman siklus I ke siklus II meningkat sebanyak 53\% lalu dilanjutkan dengan peningkatan dari siklus II ke siklus II sebanyak 29\%. Ssedangkan untuk hasil kemampuan membaca pemahaman siklus I ke siklus II meningkat sebanyak $41 \%$ dan dilanjutkan dengan peningkatan dari siklus II ke siklus III meningkat sebanyak $37 \%$.

Dengan kata lain, hasil penelitian ini dapat menjawab rumusan masalah bahwa model Multiliterasi dapat meningkatkan kemampuan membaca pemahaman siswa kelas V SDN Trajaya III Kecamatan Palasah Kabupaten Majalengka, sehingga model Multiliterasi dapat dijadikan salah satu alternative bagi guru dalam melaksanakan kegiatan belajar mengajar di kelas khusunya dalam kemampuan membaca pemahaman.

\section{SIMPULAN}

Berdasarkan hasil analisis data penelitian tindakan kelas dengan menerapkan model pembelajaran Multiliterasi untuk meningkatkan kemampuan membaca pemahaman siswa pada materi menyimpulkan cerita anak di kelas V SDN Trajaya III Kecamatan Palsah Kabupaten Majalengka dapat disimpulkan bahwa :

1. Peningkatan kemampuan membaca pemahaman dengan model multiliterasi dinyatakan berhasil. Hal tersebut berdasarkan hasil evaluasi yang diperoleh pada tindakan siklus III yaitu sebesar 96\% pada proses kemampuan membaca pemahaman dan $85 \%$ pada ketuntasan nilai tes hasil kemampuan membaca pemahaman dimana kedua nilai tersebut melebihi nilai persentase keberhasilan penelitian sebesar $85 \%$ maka siklus berhenti pada siklus III dan dinyatakan bahwa penerapan model Multiliterasi dapat meningkatkan kemampuan membaca pemahaman siswa pada kelas V SDN Trajaya III Kecamatan Palasah Kabupaten Majalengka.

2. Simpulan ini diperkuat dengan peningkatan proses kemampuan membaca pemahaman siklus I ke siklus II meningkat sebanyak 53\% lalu dilanjutkan dengan peningkatan dari siklus II ke siklus II sebanyak 29\%. Ssedangkan untuk hasil kemampuan membaca pemahaman siklus I ke siklus II meningkat sebanyak $41 \%$ dan dilanjutkan dengan peningkatan dari siklus II ke siklus III meningkat sebanyak $37 \%$.

Berdasarkan simpulan tersebut, peneliti menyampaikan saran berdasarkan hasil penelitian, ternyata hanya sebagian faktorfaktor penyebab terjadinya masalah yang diteliti, masih banyak faktor lainnya yang belum di teliti, oleh karena itu, untuk para peneliti laim agar dapat melanjutkan penelitian tentang faktor-faktor tersebut. Selain itu, model multiliterasi dianggap sebagai suatu model yang baru di Indonesia maka dari itu diharapkan peneliti lain mampu meneliti berbagai faktor yang menjadi kelemahan dalam pembelajaran menggunakan dengan model multiliterasi ini.

\section{DAFTAR PUSTAKA}

Abidin, Y. (2015) Pembelajaran Multiliterasi: Sebuah Jawaban Atas Tantangan Pendidikan Abad Ke-21. Bandung: Rafika Aditama. (2016) Revitalisasi Penilaian Pembelajaran Dalam Konteks Pendidikan Multiliterasi Abad ke21. Bandung: Rafika Aditama.

Arifin, Z. (2009). Evaluasi Pembelajaran. Bandung: PT. Remaja Rosdakarya

Boche, B (2014) Multiliteracies in The Classroom: Emerging Conceptions of First Year Teacher.Journal of Language and Literacy Education [Online] Tersedia: http://jolle.coe.uga.edu.

Kurniawan, M.Y (2016) Peningkatan Keterampilan Membaca Pemahaman Dengan Menggunakan Strategi 
Direct Reading Thinking Activity (DRTA). Universitas sebelas Maret

Moore, Amy L (2017) A Research Review of Cognitive Skills, Strategies and Interventions for Reading Comperhension. [Online] Tersedia: http://download.learningrx.com/readi ng-comperhension-researchpaper.pdf.

OECD (2015) Literacy Skills for the World of Tomorrow-Futhe Results From PISA. Organization for Economic Cooperation and Development and UNESCO Institute for Statistic.

Susilo, S. V. (2016a) 'Metode Pembelajaran Pengetahuan Awal Terhadap Kemampuan Membaca Pemahaman Siswa', Pendidikan Dasar, (2), pp. 150-167. doi: https://doi.org/10.21009/JPD.071.13.

Susilo, S. V. (2016b) 'Pengaruh Model Team Games Turnamen Dan Grup Investigasi Serta Pengetahuan Awal Siswa Terhadap Kemampuan Membaca Pemahaman', Cakrawala Pendas, 2(2), pp. 58-70. Available at: https://www.google.co.id/url?sa=t\&rc $\mathrm{t}=\mathrm{j} \& \mathrm{q}=\&$ esrc $=\mathrm{s} \&$ source $=$ web $\& \mathrm{~cd}=1$ $\& \mathrm{cad}=$ rja\&uact $=8 \&$ ved $=0$ ahUKEwih 5OKWnZbaAhXEkJQKHec4BxsQFg grMAA\&url=http $\% 3 \mathrm{~A} \% 2 \mathrm{~F} \% 2 \mathrm{Fwww}$ .unma.ac.id\%2Fjurnal\%2Findex.php $\% 2 \mathrm{FCP} \% 2$ Farticle $\% 2$ Fdownload $\% 2 \mathrm{~F}$ 334\%2F314\&usg=AOvVaw3Rf4lRv OynwJO4hRyE1G--.

Tarigan, H.G (2008) Menulis Sebagai Suatu Keterampilan Berbahasa. Bandung: Aksara

Wolley, G (2011) Assisting Children with Learning Difficulties. [Online] http://www.springer.com/978-94007-1173-0

Yukselir, C (2014) An Investigation Into The Reading Strategy Use Of EFL PrepClass Students. Osmaniye Korkut Ara University. 